\title{
Article \\ Debating Europe: Effects of the "Eurovision Debate" on EU Attitudes of Young German Voters and the Moderating Role Played by Political Involvement
}

\author{
Jürgen Maier ${ }^{1, *}$, Berthold Rittberger ${ }^{2}$ and Thorsten Faas ${ }^{3}$ \\ ${ }^{1}$ Department of Political Science, University of Koblenz-Landau, 76829 Landau, Germany; E-Mail: maierj@uni-landau.de \\ ${ }^{2}$ Department of Political Science, University of Munich, 80538 Munich, Germany; \\ E-Mail: berthold.rittberger@gsi.uni-muenchen.de \\ ${ }^{3}$ Department of Political Science, University of Mainz, 55122 Mainz, Germany; E-Mail: thorsten.faas@uni-mainz.de \\ * Corresponding author
}

Submitted: 30 September 2015 | Accepted: 8 January 2016 | Published: 29 February 2016

\begin{abstract}
In the run-up to the elections to the European Parliament in 2014, EU citizens had the unprecedented opportunity to watch televised debates between the candidates running for president of the European Commission. The most important debate was the so-called "Eurovision debate", which was broadcasted in almost all EU member states. In this study we explore the responses of a sample of 110 young German voters, who watched this debate, to the candidates' messages and whether exposure to the debate caused a shift in the respondents' attitudes towards the EU. Combining data from a quasi-experiment, real-time response data, and data from a content analysis of the debate, we find that respondents' reactions to the candidates' statements were-on average-positive and that some respondents displayed attitudinal changes resulting in more favorable views towards the EU. Although the direct connection between realtime responses and post-debate attitudes is not as strong as expected, most of the measured effects indicate that a positive evaluation of the candidates' messages usually results in more pro-European attitudes. Furthermore, we find no strong evidence that political knowledge moderates debate effects. In general, differences between political 'novices' and political 'experts' tend to be rare.
\end{abstract}

\section{Keywords}

EU attitudes; European election; evaluation of candidate statements; political knowledge; televised debates

Issue

This article is part of the issue "How Different Were the European Elections of 2014?", edited by Wouter van der Brug, Katjana Gattermann and Claes de Vreese (University of Amsterdam, The Netherlands).

(C) 2016 by the authors; licensee Cogitatio (Lisbon, Portugal). This article is licensed under a Creative Commons Attribution 4.0 International License (CC BY).

\section{Introduction}

In the run-up to the 2014 European Parliament (EP) elections, the candidates running for the office of president of the European Commission participated in several televised pan-European debates, a novelty in the EU's history. Among the series of debates, the so-called "Eurovision debate", which was held on May $15^{\text {th }} 2014$, stood out as the single most important debate. In con- trast to all other debates, this event was not only broadcasted in the vast majority of EU member states, it also featured the five major candidates running for president of the European Commission (for an overview see Maier \& Faas, 2014b). For the first time in the EU's history, an overwhelming majority of EU citizens thus had an unprecedented opportunity: they could directly compare the candidate's positions and personalities in a televised debate, a well-known campaign for- 
mat in the context of national elections and where it has turned out be a powerful campaigning tool in the run-up to elections.

There is a large body of literature on the impact of televised debates in national elections (for an overview see, e.g., McKinney \& Carlin, 2004). This research has demonstrated that debates can have-among other things-effects on prospective voters' cognitive and political involvement, attitudes towards candidates and issues, turnout, and voting behavior. In this contribution, we focus on the influence of debates on political attitudes towards candidates and issues, the impact of which is heavily disputed in the literature. While a meta-analysis by Benoit, Hansen, and Verser (2003) indicates that viewing televised debates can affect issue preferences and attitudes respondents hold towards the candidates (see also, e.g., Abramowitz, 1978; Geer, 1988; Lanoue \& Schrott, 1989a, 1989b), most studies on debates in the U.S. suggest that debates reinforce already existing attitudes rather than transforming them (see, e.g., Chaffee, 1978; Hagner \& Rieselbach, 1978; Katz \& Feldman, 1962; Kraus, 2000; McKinney \& Carlin, 2004). These findings are in line with the results from classical campaign research that the reinforcement of attitudes is the most important campaign effect. Mechanisms of selective exposure and selective information processing usually prevent individuals from receiving 'wrong' information, i.e. information contradicting their views, and thus, from changing their attitudes (Lazarsfeld, Berelson, \& Gaudet, 1944). For Germany, it has been demonstrated that-at least in the short run-a significant part of the electorate changed their opinions about the respective candidates running for chancellor after watching a debate (for a summary see, e.g., Maier, Faas, \& Maier, 2014). It has been argued that selective information processing is rendered more difficult in the case of televised debates than for other types of campaign messages. Empirically, is has been shown that televised debates make it more difficult for recipients to permanently block messages from the political opponent. Hence, candidates have not only the opportunity to "preach to the converted" (Norris, 2003) but also to influence independent voters as well as supporters of the political opponent (Faas \& Maier, 2004; Maier \& Faas, 2011). With respect to the Eurovision debate, research indicates that exposure to campaign messages also affects candidate evaluations. Most of the candidates for Commission president were perceived more favorably after watching the debate (Dinter \& Weissenbach, 2015).

Since the early days of research on the effects of campaign communication, it has been claimed that voters lacking political knowledge and political interest are most likely to be persuaded by campaign messages (see, e.g., Lazarsfeld et al., 1944). This implies, in turn, that voters' level of political involvement is a factor that moderates the impact of new information on po- litical attitudes and behavior. The reason for this relationship is that voters with a higher level of cognitive and political involvement are more likely to hold strong attitudes towards politics (see, e.g., McGraw \& Ling, 2003). Moreover, a higher level of knowledge about politics enables voters to create counterarguments to protect themselves against persuasive messages (see, e.g., Matthes \& Marquard, 2013; Reinemann \& Maurer, 2010). Hence, new information will not change their attitudes as easily as is the case for voters displaying low levels of political involvement (lyengar, Peters, Kinder, \& Krosnick, 1984; Krosnick \& Kinder, 1990). In turn, it has been argued that with increasing levels of political knowledge the likelihood of attitudinal changes also rises. Individuals with higher levels of cognitive abilities are able to process a message more profoundly (see, e.g., Delli Carpini, \& Keeter, 1996; Krosnick \& Brannon, 1993; Petty \& Cacioppo, 1986; Zaller, 1992). This is particularly important if a message includes complex information (which is true for most information about politics in general, and should particularly apply to the multi-level character of EU politics). As a consequence, voters who do not possess the required knowledge to properly process relevant political information are more likely to brush the message aside. In contrast, voters with political expertise tend to think more carefully about political information and the likelihood to be affected by information thus increases (Hwang, Gotlieb, Nah, \& McLeod, 2007).

Evidence that campaign information-or, more generally, information provided by the mass mediahas such a conditional impact on attitudes is, however, mixed. While some studies find that campaign or media effects are stronger for voters with low levels of political involvement (e.g., Hwang et al., 2007; Kinder \& Sanders, 1990; Matthes \& Marquard, 2013), other studies find no effect or even the opposite relationship (e.g., Krosnick \& Brannon, 1993; Nelson, Clawson, \& Oxley, 1997; Young, 2004).

This inconclusive pattern also appears to be characteristic of EP election campaigns, most notably with regard to media effects on EU attitudes and behavior. With respect to political attitudes, Schuck and de Vreese (2006) demonstrated that the impact of media frames on public support for EU enlargement is moderated by political knowledge. Individuals with low levels of political knowledge were, in general, more affected by news frames than individuals with higher knowledge levels. Moreover, they were more susceptible to risk framing than citizens with high levels of political knowledge. In addition, Schuck, Boomgaarden and de Vreese (2013) showed that citizens who are less aware of election campaigns tend to become more cynical when consuming news through the media. With respect to electoral behavior, Blumler (1983) was able to demonstrate for the first EP election that exposure to televised campaign information had a particularly 
positive impact on turnout for voters with a strong interest in the campaign. In contrast, Schönbach (1983) found that the impact of the mass media on turnout is somewhat stronger for voters with low campaign interest. In addition, Cayrol (1991) indicated that mass media information about the 1989 EP election campaign had no impact on voters displaying high levels of involvement. For the 1999 election, Schönbach and Lauf (2002) found the impact of TV exposure to make no difference for involved and uninvolved voters. Moreover, their results indicate that newspaper consumption and interpersonal communication mobilized the rather less involved voters. Analyzing the 2009 EP elections, De Vries, Van der Brug, Van Egmond and Van der Eijk (2011) found issue voting to be slightly more pronounced among politically sophisticated voters and in contexts that provide higher levels of EU-related information (see also Hobolt, 2005).

With respect to televised debates, there is very little research on the moderating impact of political involvement on debate effects. Druckman (2003) demonstrated that citizens with low levels of political sophistication exposed to the 1960 Kennedy-Nixon debate learned more than politically sophisticated voters. Furthermore, Reinemann and Maurer (2010) showed for the 2005 German televised debate that political interest neither affected the perception of the debate nor did it moderate the impact of the debate on attitudes towards candidates.

The differential impact of political involvement on the magnitude of campaign effects can be traced back to a number of factors (see also Lecheler \& de Vreese, 2011; Lecheler, de Vreese, \& Slothuus, 2009). First, studies assessing the moderating impact of political involvement differ substantially in their operationalization of the concept. Whereas some researchers use measures of interest or awareness, others rely on measures of knowledge. Although all of these measures are positively correlated they tap into different microlevel processes. Whereas interest and awareness focus on motivations, knowledge is about cognitions. Second, while standard items to measure political knowledge are lacking, scholars largely agree on how to measure the motivational aspects of political involvement. Hence, different results on the moderating role of political knowledge might by simply a result of different operationalizations. Third, the impact of political involvement might vary with the dependent variable in focus.

The aim of this paper is to contribute to the body of research exploring the effects of televised debates. In particular, we are interested in how recipients process the information provided by the Eurovision debate and the impact of watching the debate on EU attitudes. In addition, we want to investigate whether political involvement plays a moderating role for the influence of such a debate. To this effect, we analyze the relationship between debate exposure, debate effects, and political involvement for the 2014 Eurovision debate among young German voters. Recent research has shown that watching this debate affected candidate evaluations and attitudes toward the EU (Dinter \& Weissenbach, 2015; Maier, 2015). Unfortunately, the studies available to date did not investigate if the effects of the Eurovision debate are similar across different groups of voters.

Research on EU attitudes of young voters is relatively scarce. Existing studies indicate that young voters are usually better informed about the EU (e.g., Maier \& Bathelt, 2013), tend to hold more pro-European attitudes (e.g., Boomgaarden, Schuck, Elenbaas, \& de Vreese, 2011), and yet they are less likely to participate in EP elections (e.g., Bhatti \& Hansen, 2012). It is noteworthy, though, that there is a general lack of studies focusing on the effects of campaign communication on this voter segment in general (see, e.g., Kaid, McKinney, \& Tedesco, 2007) and with regard to the EU in particular (e.g., Esser \& de Vreese, 2007). Hence, our study contributes to learning about the impact of a major campaign message on citizens who had the first opportunity to cast their vote at the European level.

\section{Research Design}

On May $15^{\text {th }} 2014$, seven days before the beginning of the election period (May $22^{\text {nd }}-25^{\text {th }}$ ), the European Broadcasting Union (EBU) aired what has become known as the "Eurovision Debate". For a duration of 90 minutes, the top candidates of the five major political groups represented in the EP-Jean-Claude Juncker (European People's Party), Martin Schulz (Progressive Alliance of Socialists and Democrats), Guy Verhofstadt (Alliance of Liberals and Democrats for Europe), Ska Keller (The Greens-European Free Alliance), and Alexis Tsipras (European United Left-Nordic Green Left)discussed the most pressing problems facing the EU. The debate took place in the plenary chamber of the $E P$ in Brussels in front of a large audience.

According to information provided by the EBU, the debate was broadcasted in more than 30 countries all over the world by 49 TV stations, 10 radio stations, and via 39 Internet live streams. ${ }^{1}$ As Monica Maggioni, one of the moderators of the debate, pointed out at the beginning of the televised program, the potential reach of the debate encompassed 400 million voters. Since EP election campaigns differ from country to country, the debate can be seen to serve as a common point of reference for the entire EU (see also Benoit, 2014, p. 4). Against this backdrop, the debate performed poorly.

\footnotetext{
${ }^{1}$ According to the EP, the debate was available on television in 26 EU member states. In addition, the EP provided a live stream on its web site. In Estonia and the Netherlands the debate was available only via Internet. In Denmark and Finland the debate was videotaped and broadcasted the next day (see http://www.europarl.europa.eu/pdf/divers/broadcasters.pdf)
} 
For example, only 160.000 citizens in Germany watched the debate (market share: $0.5 \%),{ }^{2}$ which was aired by Phoenix TV, a publicly owned news channel.

In order to capture the effects of the Eurovision debate on young voters, we set up a study totaling 130 students enrolled at the universities of KoblenzLandau, Mainz, and Munich. The impact of the debate was measured employing an experimental pretestposttest design. The participants watched the debate live on large screens in university lecture auditoriums or seminar rooms. Immediately before and immediately after the debate, the participants were asked to fill in detailed questionnaires, which included questions about their social profile, political knowledge about the EU, attitudes towards politics in general, towards the $\mathrm{EU}$ and the candidates running for presidency, as well as their voting intentions for the upcoming elections. We assessed the direct impact of debate exposure by comparing pre- and post-debate values of the dependent variables of our analysis (i.e., EU attitudes; for wording and coding of all variables see appendix). In order to analyze if the debate had conditional effects on voters displaying different levels of political involvement, we used political knowledge as a moderator variable. This is in line with the results provided by Zaller (1992) who has evaluated different measures of political awareness, finding that factual knowledge is the best measure in this case (see also Converse, 2000; for the operationalization of this variable see appendix). ${ }^{3}$

2 See http://www.quotenmeter.de/n/70768/phoenix-europa wahl-erreicht-kaum-zuschauer

3 As there is no standard scale to measure either political
Our analysis is based on 110 respondents (KoblenzLandau: $N=45$, Mainz: $N=36$, Munich: $N=29$ ) for whom we measured computer-based real-time judgments during the course of the debate. The utilized real-time response (RTR) system employs the so-called push button technique. Whenever participants had a favorable or unfavorable impression of the debate, they were asked to indicate this by pushing the relevant button. Two keys were clearly marked on a customary computer keyboard, hence allowing participants to make positive and negative judgements independently. The keys corresponded to the design of the computer screen that participants had in front of them (see Figure 1). Whenever a

knowledge or knowledge about the EU in particular, we captured political knowledge with three items on factual knowledge about the EU. All variables have a sufficient item difficulty ( $M=69.7$, minimum 60.9, maximum 74.5 ). The distribution of our knowledge index is as follows: 7 percent no correct answer, 21 percent one correct answer, 27 percent two correct answers, 45 percent three correct answers. The average number of correct answers is $M=2.1(S D=1.0)$. The standardized reliability (Kuder-Richardson formula 20) of the scale is $r=.51$. Although, reliability is clearly below the cutoff value considered as adequate by most researchers, Schmitt (1996, pp. 351-352) argues that even scales with reliability scores as low as in our case might be useful "when a measure has other desirable properties such as meaningful content coverage of some domain and reasonable unidimensionality". Both criteria are met here: first, a factor analysis yields only one dimension. Hence, our scale is homogenous. Second, as the wording of our knowledge items indicate, all of them refer to the EU. In addition, all items are positively correlated (mean inter-item correlation .26; minimum: .16, maximum: .41). All items of the scale are thus related in a meaningful way to the domain in focus.

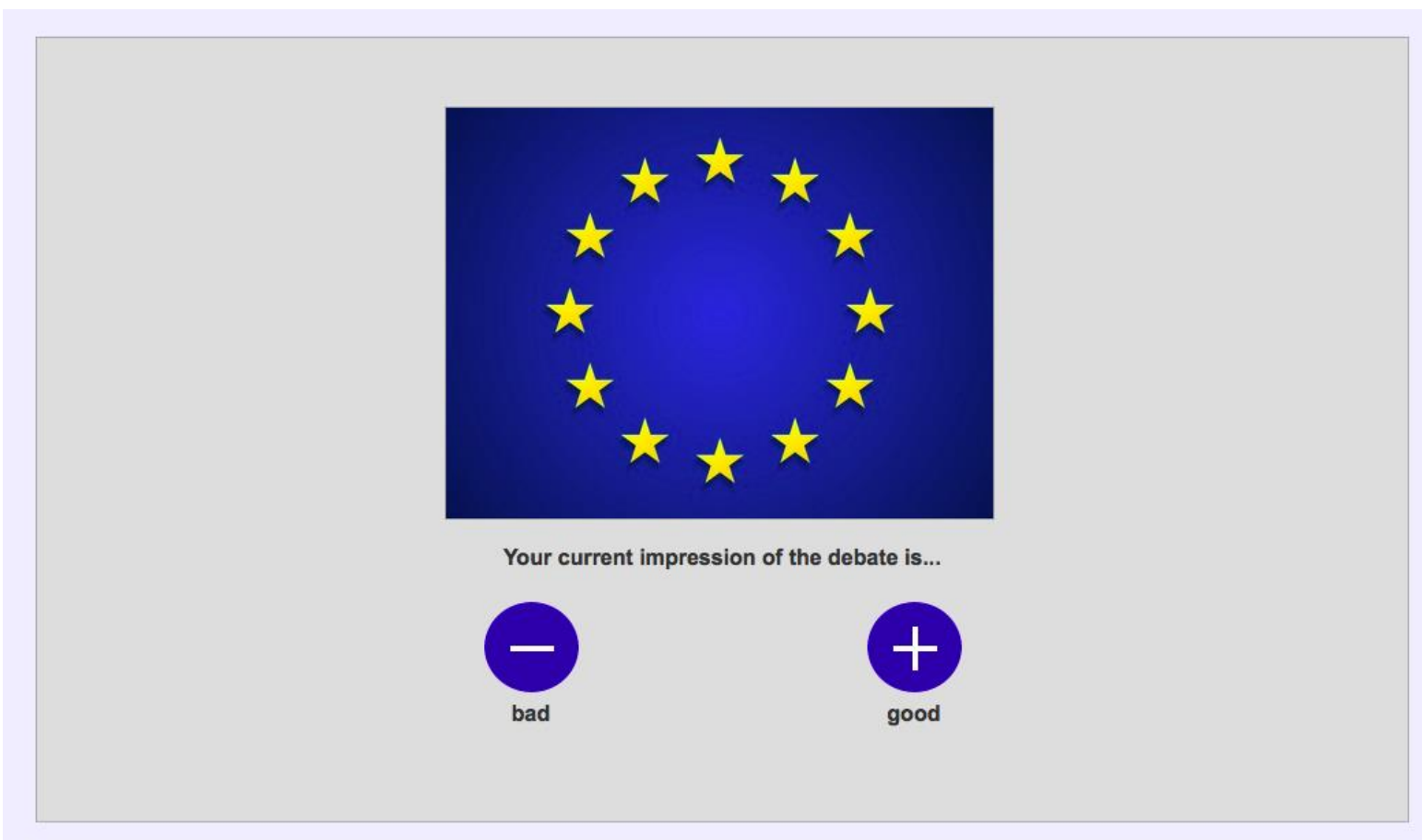

Figure 1. RTR screen. 
participant decide to strike one of the keys, the respective symbol on the screen flashed up to confirm the stroke. The RTR-system yields categorical data about positive and negative impressions of the debate on a second-by-second base. Previous research indicates that the RTR data is reliable and valid (see, e.g., Maier, Maurer, Reinemann, \& Faas, 2007).

In order to connect real-time responses with the content of the debate, we carried out a content analysis of the Eurovision debate. Based on the German transcript of the debate (Maier \& Faas, 2014a; for an English transcript see Maier \& Faas, 2014b), we first disaggregated the debate content into single statements. These single statements are our unit of analysis. A statement is considered to be complete if the speaker, the content, the object, or the strategy changed. In order to match the content of the statements with recipients' real-time responses we identified the exact beginning as well as the exact end of each message. Second, we separated functional from non-functional units. Non-functional units are statements that were incomplete, i.e. that they were not intelligible. Third, all functional units addressed by candidates were coded (e.g., the topic of the statement). For the purpose of our analysis we only employ information about which candidate was speaking at a particular point of the debate.

Our student sample is, of course, a convenience sample. Although research has indicated that there is nothing wrong with student samples in experimental research per se (Druckman \& Kam, 2009), we have to acknowledge that the distribution of some of the items used in our analysis might be biased due to the structure of the sample (for instance, assessments about the most pressing problems Germany is facing). Nevertheless, as the focus of our study is on campaign effects, this kind of bias should not be a problem. Most of the respondents are students of political or social science study programs (79\%). 56 percent of the participants are female. The average age is 22.0 years $(S D=2.9)$. Based on a self-placement on an eleven-point ideology scale from 0 ("left") to 10 ("right") our sample is slightly biased to the left $(M=3.7, S D=1.6)$. In addition, the participants of our study view the EU favorably: prior to the debate, 84 percent viewed Germany's membership in the EU as a "good thing", 16 percent believed that being part of the EU is "neither good nor bad" for Germany, and only one percent indicated that Germany's EU membership is a "bad thing". ${ }^{4}$

4 Our sample is neither representative for Germany nor for young voters. Nevertheless, we have no indication that the processing of the debate and its effects are different for voters not included in our sample. Because we are interested in the effect of the debate (and not in distributions of EU attitudes), we assume that our findings are valid for young and welleducated German voters in general.

\section{Results}

\subsection{Perception of the Candidates' Statements}

To assess the individual perception of the candidates' statements we make use of the data obtained through RTR measurement. In total, we received 29,746 realtime responses during the debate. 24,619 (82.8 percent) of these responses were direct reactions to the candidates speaking. On average, every participant exercised a key-stroke 223.8 times during the debate. ${ }^{5}$ Since the duration of the debate was 5,380 seconds, recipients reacted to what the candidates said by pushing one of the keys about every 24 seconds. The majority of reactions to the candidates were positive $(16,542$, i.e. 67.2 percent). Voters with low and high levels of political knowledge differed somewhat but not significantly ( $p>$.05). On average, political 'novices' stroke a key 196.9 times (i.e. about every 27 seconds). Political 'experts' reacted, on average, 234.4 times to what the candidates had to say (i.e. about every 23 seconds). In addition, the share of positive responses is quite similar as well (65.6 vs. 67.6 percent, $p>.05$ ). With respect to the candidates, Keller received most of the spontaneous responses $(6,501$, i.e. 26.4 percent), followed by Verhofstadt $(5,487$, i.e. 22.3 percent), Juncker $(4,916$, i.e. 20.0 percent), Tsipras $(4,193$, i.e. 17.0 percent), and Schulz $(3,522$, i.e. 14.3 percent). This ranking is similar for respondents with low and high knowledge levels.

In order to keep our research as transparent and comprehensible as possible, we draw on the individual balance between a candidate's share of positive and his/her share of negative reactions for all subsequent analyses (for this approach see also Faas \& Maier, 2004). Based on this measure, a score of $+100(-100)$ indicates that a respondent's reaction towards a candidate is exclusively positive (negative). A score of 0 indicates that positive and negative reactions are in balance, or that a candidate received no response at all. Using this measure, Table 1 indicates that Keller (+73.1) and Schulz $(+71.9)$ are clearly ahead of Verhofstadt (+39.6) and Juncker (+34.2). Tsipras obtained the worst, albeit still positive balance $(+10.7)$.

If we disaggregate the evaluation of the candidates' debate performance by issue block, it becomes apparent that the candidates performed very differently during the course of the debate (see Table 2). Juncker received most support when he talked about the acceptance of religious symbols in Europe $(+50.2)$ and about the refugee issue (+48.9). He performed worst when he explained measures to overcome Euroskepticism (-2.3). Schulz had his best moments when he outlined his plans

\footnotetext{
${ }^{5}$ Note that there is a large variation for the number of individual responses to the candidates. The minimum number of reactions is 14 , the maximum number is 2,036 . The standard deviation is 305.2 .
} 
Table 1. Mean balance between the share of positive and negative real-time responses to candidate statements by candidate and topic.

\begin{tabular}{|c|c|c|c|c|c|}
\hline & Juncker & Schulz & Verhofstadt & Keller & Tsipras \\
\hline Debate as a whole & +34.2 & +71.9 & +39.6 & +73.1 & +10.7 \\
\hline \multicolumn{6}{|l|}{ Blocks of issues } \\
\hline Opening statement & +17.0 & +4.3 & +9.2 & +59.9 & -9.1 \\
\hline Youth unemployment & +38.9 & +62.9 & +42.1 & +62.5 & -1.8 \\
\hline Austerity & +20.4 & +38.5 & -23.4 & +57.5 & -20.8 \\
\hline Regulations of banks & +31.2 & +35.5 & +15.0 & +54.6 & -1.6 \\
\hline Euroskepticism & -2.3 & +48.9 & +18.6 & +54.9 & -12.8 \\
\hline Ukraine crisis & +37.8 & +60.9 & +40.8 & +73.7 & +37.0 \\
\hline Independent movements & +39.1 & +50.4 & +18.6 & +39.5 & +25.1 \\
\hline Refugees & +48.9 & +43.6 & +48.9 & +69.1 & +21.2 \\
\hline Religious symbols & +50.2 & +49.4 & +55.0 & +66.2 & +37.6 \\
\hline Turnout & +25.6 & +65.1 & +22.9 & +56.9 & +4.9 \\
\hline Lobbyism and corruption & +29.7 & +48.6 & +71.5 & +55.9 & +24.6 \\
\hline President of EU commission & +24.5 & +41.4 & +11.2 & +29.8 & -1.4 \\
\hline Closing statements & +28.2 & +52.7 & +23.7 & +33.2 & +13.2 \\
\hline
\end{tabular}

Table 2. Mean balance between the share of positive and negative real-time responses to candidate statements by candidate and topic by voters with low and high level of political knowledge.

\begin{tabular}{|c|c|c|c|c|c|c|c|c|c|c|}
\hline & \multicolumn{5}{|c|}{ Low knowledge } & \multicolumn{5}{|c|}{ High knowledge } \\
\hline & Juncker & Schulz & $\begin{array}{l}\text { Verhof- } \\
\text { stadt }\end{array}$ & Keller & Tsipras & Juncker & Schulz & $\begin{array}{l}\text { Verhof- } \\
\text { stadt }\end{array}$ & Keller & Tsipras \\
\hline Debate as a whole & +44.7 & +61.4 & +42.0 & +74.2 & +6.3 & +30.1 & +76.0 & +38.7 & +72.6 & +12.4 \\
\hline \multicolumn{11}{|l|}{ Blocks of issues } \\
\hline Opening statement & +34.1 & +3.2 & +19.4 & +61.3 & -24.7 & +10.3 & +4.7 & +5.1 & +59.3 & -3.0 \\
\hline Youth unemployment & +48.0 & +61.5 & +46.0 & +61.3 & +9.7 & +35.4 & +63.5 & +40.5 & +63.0 & -6.3 \\
\hline Austerity & +19.4 & +34.0 & -7.0 & +60.8 & -10.6 & +20.8 & +40.3 & -29.9 & +56.2 & -24.9 \\
\hline Regulations of banks & +44.8 & $+9.7^{b}$ & +16.1 & +50.0 & -5.0 & +25.9 & +45.7 & +14.6 & +56.4 & -0.3 \\
\hline Euroskepticism & +8.5 & $+27.4^{\mathrm{a}}$ & +16.7 & +52.7 & -9.6 & -6.6 & +57.4 & +19.4 & +55.7 & -14.0 \\
\hline Ukraine crisis & +33.5 & +51.0 & +20.2 & +79.6 & +32.6 & +39.5 & +64.8 & +48.9 & +71.4 & +38.7 \\
\hline Independent movements & +32.3 & +44.5 & +37.9 & +32.3 & +17.4 & +41.8 & +52.7 & +11.2 & +42.3 & +28.2 \\
\hline Refugees & +45.2 & +35.5 & +51.6 & +64.5 & +14.8 & +50.3 & +46.8 & +47.9 & +70.9 & +23.7 \\
\hline Religious symbols & +64.5 & $+30.1^{\mathrm{a}}$ & +49.7 & +70.9 & +28.7 & +44.6 & +56.9 & +57.1 & +64.4 & +41.1 \\
\hline Turnout & +27.6 & +67.6 & $+0.3^{a}$ & +65.9 & -2.2 & +24.7 & +64.1 & +31.8 & +53.4 & +7.6 \\
\hline Lobbyism and corruption & +30.1 & $+28.0^{a}$ & +68.8 & +58.6 & +16.1 & +29.5 & +56.6 & +72.5 & +54.8 & +27.9 \\
\hline President of EU commission & +16.1 & +40.3 & +12.6 & $+9.7^{\mathrm{a}}$ & +6.5 & +27.8 & +41.8 & +10.7 & +37.6 & +0.6 \\
\hline Closing statements & +38.7 & $+23.2^{c}$ & +21.0 & +25.8 & +20.4 & +24.1 & +64.3 & +24.8 & +36.1 & +10.3 \\
\hline $\mathrm{N}$ & & & 31 & & & & & 79 & & \\
\hline
\end{tabular}

Note: $a: p<.05, b: p<.01, c: p<.001$.

to confront the low turnout in EP elections (+65.1), to reduce youth unemployment (62.9), and when he highlighted his position on the Ukraine crisis (+60.9). His weakest performance was during his opening statement (+4.3). Verhofstadt performed best when addressing lobbyism and corruption (+71.5). He was judged least favorably when he talked about austerity (-23.4). Keller performed very strong during all phases of the debate. She obtained her best scores with her position on the Ukraine crisis (73.7), and was deemed least convincing when she talked about the future role of the presidency of the European Commission (+29.8), as well as during her closing statement $(+33.2)$. For Tsipras the picture was more mixed than for the other candidates. While his arguments on religion $(+37.6)$ and the Ukraine crisis $(+37.0)$ were received favorably, he faced negative responses on several issues: His posi- tion on austerity (-20.8) and his explanation about why the EU is often seen critically by citizens $(-12.9)$ were the most unpopular. If we compare the perceived performance of the candidates across issues, Keller performed most successfully. She 'won' in seven out of thirteen issue blocks, including the opening statement. Schulz received the best ratings on five issues, including the closing statement. Verhofstadt performed best on one issue (lobbyism and corruption), while Tsipras and Juncker did not ' $w i n$ ' any of the thematic blocks.

How successful was the perceived performance of the candidates with respect to the recipients' level of political knowledge about the EU? Our results indicate that both groups of voters - those with high and low knowledge levels - reacted quite similarly to the candidates' statements (see Table 2). Focusing on the debate as a whole, we do not find any significant differ- 
ences between 'experts' and 'novices' ( $p>.05$ ). If we analyze the reactions to the candidates by issue blocks we find some statistically significant differences $(p<.05)$, albeit only for Schulz, Verhofstadt and Keller. All of these differences point in the same direction: respondents with a high level of political knowledge were more impressed by the candidate statements than less knowledgeable voters. If we add gender, ideology, and diffuse support for the EU as control variables, four group differences remain significant $(p<.05)$. On the one hand, Schulz was able to convince 'experts' more than 'novices' when he talked about Euroskepticism, lobbyism and corruption, as well as during his closing statement. On the other hand, subjects with a high level of political knowledge showed more support for Verhofstadt on the issue of turnout than voters with lower levels of factual knowledge.

In sum, the candidates left more positive than negative impressions among our audience of students. The real-time reactions of recipients with a low level of political knowledge and those of political 'experts' differ only for some candidates and for some issues. After controlling for variables, which potentially explain the differences between these two groups of voters, it turns out that only a few of the original effects remain significant. Interestingly enough, our results indicate that respondents with higher levels of political knowledge tend to be more persuaded by the candidates than those with lower levels of knowledge.

\subsection{Impact of the Debate on Political Attitudes}

One of our most important findings is that exposure to the Eurovision debate led to only minor attitudinal changes (see Table 3 ). Overall, we observe only two changes reaching conventional significance levels $(p<.05)$. First, watching the debate causes an increasing willingness among respondents to favor further European integration (+.35 scale points). Second, exposure to the debate leads to a decrease in fear associated with the EU (-.25 scale points). In addition, three attitude changes almost reached statistical significance. First, expectations about the development of the economy in the EU are more optimistic after the debate than before (+.11 scale points, $p=.052)$. Second, prior to the debate, the participants of our study believed that the economic situation in Germany is better than the EU's. After watching the debate, this 'national advantage' is reduced by -.10 scale points $(p=.055)$. Third, the share of subjects who believe that the most appropriate level to solve the most important problems facing Germany is the European level increased by 8.2 percentage points $(p=.060)$.

If we compare the impact of the debate for respondents with high and low levels of political knowledge, we find different effects among these groups for two out of sixteen issue blocks (see Table 4). First, the perception that the EU is the most appropriate arena to solve Germany's problems changed only moderately for participants with a high level of EUrelated knowledge (+2.5 percentage points). However, watching the debate increased the perception that the EU is an effective problem solver for political 'novices' (+22.6 percentage points). The difference between the two groups is statistically significant $(p<.05)$. Second, for respondents with a low level of political knowledge, the belief that the EU is responsible for the economic situation in Germany has solidified as a result of watching the debate $(+.46)$. In contrast, respondents with a high level of knowledge about the EU tend to believe that the EU bears less responsibility for the state of the national economy after the debate than before (-.34). These results indicate that political 'novices' and political 'experts' draw very different conclusions from the

Table 3. Impact of debate exposure on political attitudes.

\begin{tabular}{lccc}
\hline & Before the debate & After the debate & Difference \\
\hline \% EU most appropriate level to solve most pressing problem & 62.7 & 70.9 & +8.2 \\
Development of economic situation of the EU & -0.23 & -0.26 & -0.04 \\
Expected development of economic situation of the EU & 0.24 & 0.35 & +0.11 \\
Comparison of the economic situation in Germany and the EU & 1.46 & 1.36 & -0.10 \\
Responsibility of EU for economic situation in Germany & 6.64 & 6.53 & -0.11 \\
Financial support of suffering member states & 3.11 & 3.15 & +0.04 \\
Trust EU & 0.27 & 0.35 & +0.07 \\
Trust European Commission & 0.11 & 0.13 & +0.02 \\
EU good thing & 0.83 & 0.85 & +0.02 \\
Further integration & 1.75 & 2.10 & $+0.35^{\mathrm{a}}$ \\
EU: Fear & -1.64 & -1.89 & $-0.25^{\mathrm{a}}$ \\
EU: Anger & -1.34 & -1.51 & -0.19 \\
EU: Hope & 0.64 & 0.84 & +0.20 \\
EU: Joy & -0.30 & -0.04 & +0.25 \\
EU: Disgust & -1.94 & -1.99 & -0.05 \\
EU: Contempt & -0.73 & -0.70 & +0.03 \\
\hline N & 110 & 110 & 110 \\
\hline Notes: Except for the & &
\end{tabular}

Notes: Except for the first row all values are means; $a: p<.05, b: p<.01, c: p<.001$. 
Table 4. Impact of debate reception on political attitudes by political knowledge level.

\begin{tabular}{|c|c|c|c|c|c|c|c|}
\hline & \multicolumn{3}{|c|}{ Low knowledge } & \multicolumn{3}{|c|}{ High knowledge } & \multirow{2}{*}{$\begin{array}{c}\text { Difference } \\
\text { low/high } \\
\text { knowledge }\end{array}$} \\
\hline & $\begin{array}{c}\text { Before the } \\
\text { debate }\end{array}$ & $\begin{array}{c}\text { After the } \\
\text { debate }\end{array}$ & $\begin{array}{l}\text { Differ- } \\
\text { ence }\end{array}$ & $\begin{array}{c}\text { Before the } \\
\text { debate }\end{array}$ & $\begin{array}{c}\text { After the } \\
\text { debate }\end{array}$ & $\begin{array}{c}\text { Differ- } \\
\text { ence }\end{array}$ & \\
\hline \% EU most appropriate level to solve most pressing problem & 54.8 & 77.4 & $+22.6^{a}$ & 65.8 & 68.4 & +2.5 & $+20.0^{\mathrm{a}}$ \\
\hline Development of economic situation of the EU & -0.03 & -0.16 & -0.13 & -0.30 & -0.30 & 0.00 & -0.13 \\
\hline Expected development of economic situation of the EU & 0.26 & 0.29 & +0.03 & 0.23 & 0.38 & $+0.15^{\mathrm{a}}$ & -0.12 \\
\hline Comparison of the economic situation in Germany and the EU & 1.35 & 1.16 & -0.19 & 1.51 & 1.44 & -0.06 & -0.13 \\
\hline Responsibility of EU for economic situation in Germany & 6.35 & 6.80 & +0.46 & 6.76 & 6.42 & $-0.34^{a}$ & $+0.80^{\mathrm{a}}$ \\
\hline Financial support of suffering member states & 3.07 & 3.13 & +0.06 & 3.13 & 3.15 & +0.02 & 0.04 \\
\hline Trust EU & 0.13 & 0.29 & +0.16 & 0.33 & 0.37 & +0.04 & +0.12 \\
\hline Trust European Commission & -0.06 & 0.03 & +0.10 & 0.18 & 0.16 & -0.01 & +0.11 \\
\hline EU good thing & 0.74 & 0.77 & +0.03 & 0.86 & 0.87 & +0.01 & +0.02 \\
\hline Further integration & 1.63 & 2.07 & +0.44 & 1.79 & 2.11 & $+0.32^{\mathrm{a}}$ & +0.12 \\
\hline EU: Fear & -1.84 & -2.00 & -0.16 & -1.57 & -1.85 & $-0.29^{a}$ & +0.12 \\
\hline EU: Anger & -1.32 & -1.23 & +0.10 & -1.34 & -1.65 & -0.30 & +0.40 \\
\hline EU: Hope & 0.29 & 0.81 & +0.52 & 0.77 & 0.85 & +0.08 & +0.44 \\
\hline EU: Joy & -0.65 & -0.48 & +0.16 & -0.16 & 0.13 & +0.29 & -0.13 \\
\hline EU: Disgust & -1.84 & -2.06 & -0.23 & -1.97 & -1.96 & +0.01 & -0.24 \\
\hline EU Contempt & -0.48 & -0.42 & +0.06 & -0.82 & -0.81 & +0.01 & +0.05 \\
\hline $\mathrm{N}$ & & 31 & & & 79 & & 110 \\
\hline
\end{tabular}

Notes: Except for the first row all values are means; $a: p<.05, b: p<.01, c: p<.001$.

debate $(p<.05)$. For both issues, the impact of political knowledge on attitude change remains significant after controlling for gender, ideology, and diffuse support for the EU $(p<.05)$. Moreover, a third variable turns out to be significantly influenced by different knowledge levels: Exposure to the debate causes 'experts' to see the EU as less threatening than political 'novices' ( $p<.05)$.

In sum, watching the Eurovision debate created-at least in part-more favorable impressions about the EU among young and well-educated German voters. Differences between political 'experts' and 'novices' are a rare occurrence. In addition, we see no clear picture whether subjects with a low level of political knowledge or participants with a high level of knowledge are more influenced by watching the debate. In one case (responsibility of the EU for the economic situation in Germany), the reactions of the two groups of voters even move in different directions.

\subsection{Impact of the Evaluation of the Candidates' Debate Performance on Political Attitudes}

Thus far, our results indicate that exposure to the debate caused a shift in a subset of relevant EU attitudes. In addition, the subjects of our study reacted spontaneously to the statements of the candidates because they picked up pieces of information from the debate, which made them reconsider their positions towards the EU. As a consequence, we expect that the content of the debate had an impact on individual EU attitudes. In order to analyze the impact of real-time responses on post-debate attitudes we present a regression model including the evaluation of the debate performance for each of the five candidates. In addition, we include the respective post-debate attitude, gender, and ideology as control variables.

Our results indicate that the explanatory power of the response to the candidates' messages for post-debate attitudes-i.e. the increase of $R^{2}$ when adding the control variables first and the RTR values for the candidates last - tends to be rather small, with $R^{2}$ varying between .8 and 11.8 (see Table 5). Since the $R^{2}$ for the full model ranges between $R^{2}=25.9$ and $R^{2}=70.5$, the explanatory power of the candidate statements is rather modest. A closer look at the model reveals that only few of the candidate variables have a statistically significant impact on post-debate attitudes. First, support for Juncker increases the perception among respondents that the EU is the most appropriate level to solve the most pressing national problems. This relationship is reversed for Schulz. Second, support for the messages voiced by Verhofstadt increases the willingness to financially support member states suffering from the economic crisis. Third, trust in the EU increases if subjects had a positive impression of the statements by Verhofstadt, Keller, and Tsipras. Fourth, support for the messages by Keller fosters trust in the European Commission. Fifth, a positive evaluation of Schulz's statements reduces associations of hope with the EU, while sympathy for the statements by Verhofstadt decreases associations of joy as well as of disgust with the EU.

To answer the question of whether there is a conditional impact of the evaluation of the candidates' statements on post-debate attitudes, we finally analyze the minimum $R^{2}$ of these variables for each of our dependent variables for political 'novices' and political 'experts'. ${ }^{6}$ Our results indicate that the explanatory power

\footnotetext{
6 Due to small $\mathrm{N}$ for voters with a low level of political knowledge we do not discuss the regression coefficients.
} 
Table 5. Impact of real-time responses to candidate statements on post-debate political attitudes.

\begin{tabular}{|c|c|c|c|c|c|c|c|}
\hline & $\mathbf{R}^{\mathbf{2}}$ & $\begin{array}{c}\text { Min. } \mathbf{R}^{2} \\
\text { candidate } \\
\text { statements }\end{array}$ & Juncker & Schulz & $\begin{array}{l}\text { Verhof- } \\
\text { stadt }\end{array}$ & Keller & Tsipras \\
\hline \% EU most appropriate level to solve most pressing problem & 0.362 & 0.067 & $0.218^{a}$ & $-0.218^{a}$ & 0.067 & 0.056 & 0.150 \\
\hline Development of economic situation of the EU & 0.538 & 0.020 & -0.047 & -0.053 & -0.051 & -0.014 & -0.114 \\
\hline Expected development of economic situation of the EU & 0.555 & 0.017 & 0.133 & -0.010 & -0.068 & -0.018 & 0.102 \\
\hline Comparison of the economic situation in Germany and the EU & 0.432 & 0.021 & 0.040 & -0.049 & -0.072 & 0.169 & -0.062 \\
\hline Responsibility of EU for economic situation in Germany & 0.485 & 0.008 & 0.048 & -0.065 & -0.012 & 0.090 & 0.011 \\
\hline Financial support of suffering member states & 0.536 & 0.047 & -0.050 & -0.053 & $0.163^{\mathrm{a}}$ & 0.146 & -0.112 \\
\hline Trust EU & 0.570 & 0.118 & 0.074 & -0.072 & $0.208^{b}$ & $0.210^{\mathrm{b}}$ & $0.162^{\mathrm{a}}$ \\
\hline Trust European Commission & 0.479 & 0.057 & 0.113 & -0.040 & 0.027 & $0.233^{b}$ & 0.040 \\
\hline EU good thing & 0.705 & 0.003 & 0.054 & 0.008 & -0.047 & 0.032 & -0.027 \\
\hline Further integration & 0.644 & 0.005 & -0.005 & 0.014 & 0.015 & 0.069 & -0.007 \\
\hline EU: Fear & 0.526 & 0.019 & 0.084 & 0.005 & -0.153 & 0.068 & -0.053 \\
\hline EU: Anger & 0.377 & 0.018 & 0.018 & 0.021 & 0.109 & -0.064 & -0.040 \\
\hline EU: Hope & 0.259 & 0.057 & 0.092 & $-0.209^{a}$ & -0.076 & 0.187 & 0.051 \\
\hline EU: Joy & 0.420 & 0.043 & 0.090 & 0.030 & $-0.229^{a}$ & 0.075 & 0.041 \\
\hline EU: Disgust & 0.587 & 0.026 & 0.020 & -0.007 & $-0.169^{a}$ & 0.077 & -0.081 \\
\hline EU: Contempt & 0.368 & 0.051 & -0.030 & 0.020 & -0.133 & 0.063 & -0.241 \\
\hline $\mathrm{N}$ & & & & 110 & & & \\
\hline
\end{tabular}

Notes: All models control for pretest value of the dependent variable, ideology, and gender. Displayed are standardized regression coefficients; $a: p<.05, b: p<.01, c: p<.001$.

Table 6. Impact of real-time responses to candidate statements on post-debate political attitudes by political knowledge.

\begin{tabular}{|c|c|c|c|c|}
\hline & \multicolumn{2}{|c|}{ Low knowledge } & \multicolumn{2}{|c|}{ High knowledge } \\
\hline & $\mathbf{R}^{2}$ & $\begin{array}{l}\text { Min, } R^{2} \text { candidate } \\
\text { statements }\end{array}$ & $\mathbf{R}^{\mathbf{2}}$ & $\begin{array}{l}\text { Min. } R^{2} \text { candidate } \\
\text { statements }\end{array}$ \\
\hline \% EU most appropriate level to solve most pressing problem & 0.303 & 0.183 & 0.482 & 0.047 \\
\hline Development of economic situation of the EU & 0.520 & 0.102 & 0.598 & 0.025 \\
\hline Expected development of economic situation of the EU & 0.508 & 0.121 & 0.638 & 0.045 \\
\hline Comparison of the economic situation in Germany and the EU & 0.344 & 0.085 & 0.546 & 0.026 \\
\hline Responsibility of EU for economic situation in Germany & 0.521 & 0.031 & 0.579 & 0.021 \\
\hline Financial support of suffering member states & 0.493 & 0.133 & 0.620 & 0.078 \\
\hline Trust EU & 0.570 & 0.280 & 0.618 & 0.078 \\
\hline Trust European Commission & 0.495 & $0.336^{b}$ & 0.583 & 0.003 \\
\hline EU good thing & 0.600 & 0.042 & 0.796 & 0.019 \\
\hline Further integration & 0.644 & 0.008 & 0.589 & 0.007 \\
\hline Fear & 0.551 & 0.136 & 0.569 & 0.016 \\
\hline Anger & 0.676 & 0.080 & 0.313 & 0.018 \\
\hline Hope & 0.299 & 0.166 & 0.334 & 0.039 \\
\hline Joy & 0.269 & 0.123 & 0.505 & 0.036 \\
\hline Disgust & 0.616 & 0.137 & 0.635 & 0.028 \\
\hline Contempt & 0.094 & 0.047 & 0.499 & 0.060 \\
\hline $\mathrm{N}$ & & 31 & & 79 \\
\hline
\end{tabular}

Notes: All models include pretest value of the dependent variable, ideology, gender, and real-time responses for the five candidates; $a: p<.05, b: p<.01, c: p<.001$.

of the real-time responses to candidate statements tends to be higher for voters with a low level of political knowledge than for knowledgeable voters (see Table 6). Only in one case-trust in the European Commission-is the difference in minimum $R^{2}$ large enough to reach conventional levels of statistical significance.

In sum, the relationship between the evaluation of the candidates' messages and EU attitudes is not as strong as expected. In most cases, the sign of the regression coefficients indicates that support for the candidates increases favorable opinions about the EU. Although our final analysis shows that political 'novic- es' tend to be more persuaded by candidate messages than political 'experts', the differences measured are statistically significant in only one instance. Interestingly enough, this conditional impact affects a variable at the center of the Eurovision debate: trust in the European Commission.

\section{Summary and Conclusion}

In 2014, the EP election campaign was characterized by the introduction of a new campaign format: a televised debate between candidates running for the presidency 
of the European Commission. Based on the vast body of research on TV debates in the domestic context, we developed the expectation that exposure to the Eurovision debate would lead to a shift in attitudes on the EU. Based on a quasi-experiment among German students we found that viewers of the debate tended to respond positively to what the candidates had to say. In addition, we were able to demonstrate that respondents changed a (small) sub-set of their EU-related attitudes due to debate exposure. Although it seems plausible that shifts in political attitudes are connected to evaluations of candidate messages, the observed relationships are not very strong. One tentative explanation for the weak relationship between candidate statements and attitude change is that the participants of our study might not perceive each message as equally salient. Unfortunately, our data does not allow us to differentiate between the relative importance respondents attach to individual reactions. Still, most of the effects we found indicate that positive evaluations of the candidates' messages result in more favorable attitudes towards the EU. However, our results do not indicate whether the measured effects are indicative of a reinforcement of already existing pro-European attitudes, or if some EU-skeptical recipients were actually persuaded by the candidates' messages. Nevertheless, the general finding that our recipients displayed more positive attitudes towards the EU ties in well with previous findings in TV debate research.

Another goal of this contribution was to analyze whether the recipients' political expertise influenced the perception and the impact of the debate. We found no major and systematic differences between political 'novices' and political 'experts' with respect to information processing, direct debate effects, and the link between spontaneous reactions to what the candidates said and EU attitudes. One explanation for the often small and statistically insignificant differences between 'novices' and 'experts' can be linked to the small sample size. Moreover, the inconclusiveness of the moderating impact of knowledge on the perception and the effects of the debate might result from the observation that the processing of debate content is much more complex than what can be captured by our models. In particular, we assume that not only is what the candidates say important for voters but also how the messages are verbalized. This might indicate that debate strategy matters.

While most of our findings suggest that the moderating role of political knowledge for the impact of the Eurovision debate as a major campaign message is limited, our results also underscore an important observation made by previous research in this field: the effect of political involvement varies with the dependent variable in focus (Lecheler \& de Vreese, 2011; Lecheler et al., 2009). One of the main results we thus draw from this analysis is that we consider the often-claimed dif- ferences between voters with low and high levels of political knowledge to be exaggerated. This is in line with other findings from debate research in the German context (Reinemann \& Maurer, 2010).

In sum, our findings highlight that televised debates in the run-up to the 2014 EP election can affect the attitudes of voters. Although our results do not provide a final and conclusive answer to the question about the impact of political knowledge on the likelihood of attitudinal change, our general finding suggests that the observed attitudinal shift leads to more positive evaluations of the EU. Hence, EU pundits should press for keeping this debate format for future elections. A prerequisite to achieving massive effects is, of course, that large parts of the electorate watch Eurovision debates. Based on the experiences of the 2014 election there is ample scope to improve the attractiveness of this campaign event.

\section{Conflict of Interests}

The authors declare no conflict of interests.

\section{References}

Abramowitz, A. I. (1978). The impact of a presidential debate on voter rationality. American Journal of Political Science, 22, 680-690.

Benoit, W. L. (2014). Political election debates. Informing voters about policy and character. Lanham: Lexington Books.

Benoit, W. L., Hansen, G. J., \& Verser, R. M. (2003). A meta-analysis of the effects of viewing US presidential debates. Communication Monographs, 70(4), 335-350.

Bhatti, Y., \& Hansen, K. M. (2012). The effect of generation and age on turnout to the European Parliament. How turnout will continue to decline in the future. Electoral Studies, 31(2), 262-272.

Blumer, J. G. (1983). Communication and turnout. In J. G. Blumler (Ed.), Communicating to voters. Television in the first European parliamentary elections. London: Sage.

Boomgaarden, H. G., Schuck, A. R., Elenbaas, M., \& de Vreese, C. H. (2011). Mapping EU attitudes. Conceptual and empirical dimensions of Euroscepticism and EU support. European Union Politics, 12(2), 241-266.

Cayrol, R. (1991). European elections and the preelectoral period. Media use and campaign evaluations. European Journal of Political Research, 19(1), 17-29.

Chaffee, S. H. (1978). Presidential debates-Are they helpful to voters? Communication Monographs, 45, 330-346.

Converse, P. E. (2000). Assessing the capacity of mass electorates. Annual Review of Political Science, 3(1), 331-353.

De Vries, C. E., Van der Brug, W., Van Egmond, M. H., \& 
Van der Eijk, C. (2011). Individual and contextual variation in EU issue voting. The role of political information. Electoral Studies, 30(1), 16-28.

Delli Carpini, M. X., \& Keeter, S. (1996). What Americans know about politics and why it matters. New Haven: Yale University Press.

Dinter, J., \& Weissenbach, K. (2015). Alles neu! Das Experiment TV-Debatte im Europawahlkampf 2014. In M. Kaeding (Ed.), Die Europawahl 2014. Spitzenkandidaten, Protestparteien, Nichtwähler. Wiesbaden, Germany: Springer VS.

Druckman, J. N. (2003). The power of television images. The first Kennedy-Nixon debate revisited. Journal of Politics, 65(2), 559-571.

Druckman, J. N., \& Kam, C. D. (2009). Students as experimental participants. A defense of the "narrow data base". In J. N. Druckman, D. P. Green, J. H. Kuklinski, \& A. Lupia (Eds.), Cambridge handbook of experimental political science. Cambridge: Cambridge University Press.

Esser, F., \& de Vreese, C. H. (2007). Comparing young voters' political engagement in the United States and Europe. American Behavioral Scientist, 50(9), 11951213.

Faas, T., \& Maier, J. (2004). Mobilisierung, Verstärkung, Konversion? Ergebnisse eines Experiments zur Wahrnehmung der Fernsehduelle im Vorfeld der Bundestagswahl 2002. Politische Vierteljahresschrift, 45(1), 55-72.

Geer, J. G. (1988). The effects of presidential debates on the electorate's preferences for candidates. American Politics Research, 16(4), 486-501.

Hagner, P. R., \& Rieselbach, L. N. (1978). The impact of the 1976 presidential debates: Conversion or reinforcement. In G. F. Bishop, R. G. Meadow, \& M. Jackson-Beeck (Eds.), The presidential debates. Media, electoral, and policy perspectives. Westport: Praeger.

Hobolt, S. B. (2005). When Europe matters. The impact of political information on voting behaviour in EU referendums. Journal of Elections, Public Opinion \& Parties, 15(1), 85-109.

Hwang, H., Gotlieb, M. R., Nah, S., \& McLeod, D. M. (2007). Applying a cognitive-processing model to presidential debate effects. Postdebate news analysis and primed reflection. Journal of Communication, 57(1), 40-59.

lyengar, S., Peters, M. D., Kinder, D. R., \& Krosnick, J. A. (1984). The evening news and presidential evaluations. Journal of Personality and Social Psychology, 46(4), 778-787.

Kaid, L. L., McKinney, M. S., \& Tedesco, J. C. (2007). Introduction. Political information efficacy and young voters. American Behavioral Scientist, 50(9), 10931111.

Katz, E., \& Feldman, J. J. (1962). The debates in the light of research. A survey of surveys. In S. Kraus (Ed.), The great debates. Background, perspectives, effects.
Bloomington: Indiana University Press.

Kinder, D. R., \& Sanders, L. M. (1990). Mimicking political debate with survey questions: The case of white opinion on affirmative action for blacks. Social Cognition, 8(1), 73-103.

Kraus, S. (2000). Televised presidential debates and public policy (2nd ed.). Mahwah, NJ: Erlbaum.

Krosnick, J. A., \& Brannon, L. A. (1993). The media and the foundations of presidential support. George Bush and the Persian Gulf conflict. Journal of Social Issues, 49(4), 167-182.

Krosnick, J. A., \& Kinder, D. R. (1990). Altering the foundations of support for the president through priming. American Political Science Review, 84(2), 497-512.

Lanoue, D. J., \& Schrott, P. R. (1989a). Voters' reactions to televised presidential debates. Measurement of the source and magnitude of opinion change. Political Psychology, 2, 275-285.

Lanoue, D. J., \& Schrott, P. R. (1989b). The effects of primary season debates on public opinion. Political Behavior, 11(3), 289-306.

Lazarsfeld, P. F., Berelson, B., \& Gaudet, H. (1944). The people's choice. How the voter makes up his mind in a presidential campaign. New York: Columbia University Press.

Lecheler, S., \& de Vreese, C. H. (2011). Getting real. The duration of framing effects. Journal of Communication, 61(5), 959-983.

Lecheler, S., de Vreese, C., \& Slothuus, R. (2009). Issue importance as a moderator of framing effects. Communication Research, 36(3), 400-425.

Maier, J. (2015). Neue Wahlkampfinstrumente als Mittel gegen die Vertrauenskrise der EU? Die Wirkung der 'Eurovison Debate' im Europawahlkampf 2014 und die Rolle der sozialen Medien. Datenschutz und Datensicherheit, 39(5), 308-311.

Maier, J., \& Bathelt, S. (2013). Unbekanntes Europa? Eine vergleichende Analyse zu Verteilung und Determinanten von Kenntnissen über die Europäische Union. In S. I. Keil \& S. I. Thaidigsmann (Eds.), Zivile Bürgergesellschaft und Demokratie. Aktuelle Ergebnisse der empirischen Politikforschung. Wiesbaden, Germany: Springer VS.

Maier, J., \& Faas, T. (2011). 'Miniature campaigns' in comparison. The German televised debates, 200209. German Politics, 20(1), 75-91.

Maier, J., \& Faas, T. (2014a). Wortlaut der Fernsehdebatte zur Europawahl 2014. Retrieved from http://www. uni-koblenz-landau.de/de/komepol/papers/workingpaper-nr-1-2014

Maier, J., \& Faas, T. (2014b). Transcript of the 'Eurovision debate' in the run-up to the European parliament election 2014. Retrieved from http://www.uni-koblenzlandau.de/de/komepol/papers/working-paper-nr-22014

Maier, J., Faas, T., \& Maier, M. (2014). Aufgeholt, aber nicht aufgeschlossen. Wahrnehmungen und Wirkun- 
gen von TV-Duellen am Beispiel von Angela Merkel und Peer Steinbrück 2013. Zeitschrift für Parlamentsfragen, 45(1), 38-54.

Maier, J., Maurer, M., Reinemann, C., \& Faas, T. (2007). Reliability and validity of real-time response measurement. A comparison of two studies of a televised debate in Germany. International Journal of Public Opinion Research, 19(1), 53-73.

Matthes, J., \& Marquard, F. (2013). Werbung auf niedrigem Niveau? Die Wirkung negativ-emotionalisierender politischer Werbung auf Einstellungen gegenüber Ausländern. Publizistik, 58(3), 247-266.

McGraw, K. M., \& Ling, C. (2003). Media priming of presidential and group evaluations. Political Communication, 20(1), 23-40.

McKinney, M. S., \& Carlin, D. B. (2004). Political campaign debates. In L. L. Kaid (Ed.), Handbook of political communication research. Mahwah, NJ: Erlbaum.

Nelson, T., Clawson, R., \& Oxley, Z. (1997). Media framing of a civil liberties conflict and its effect on tolerance. American Political Science Review, 91(3), 567-584.

Norris, P. (2003). Preaching to the converted? Pluralism, participation and party websites. Party Politics, 9(1), 21-45.

Petty, R. E., \& Cacioppo, J. T. (1986). Communication and persuasion. Central and peripheral routes to attitude change. New York: Springer.

Reinemann, C., \& Maurer, M. (2010). Leichtgläubig und manipulierbar? Die Rezeption persuasiver Wahl- kampfbotschaften durch politisch Interessierte und Desinteressierte. In T. Faas, K. Arzheimer, \& S. Roßteutscher (Eds.), Information-WahrnehmungEmotion. Politische Psychologie in der Wahl- und Einstellungsforschung. Wiesbaden, Germany: Verlag für Sozialwissenschaften.

Schmitt, N. (1996). The uses and abuses of coefficient alpha. Psychological Assessment, 8(4), 350-353.

Schönbach, K. (1983). Das unterschätzte Medium. Politische Wirkungen von Presse und Fernsehen im Vergleich. München, Germany: Saur.

Schönbach, K., \& Lauf, E. (2002). The trap effect of television and its competitors. Communication Research, 29(5), 564-583.

Schuck, A. R. T., Boomgaarden, H. G., \& de Vreese, C. H. (2013). Cynics all around? The impact of election news on political cynicism in comparative perspective. Journal of Communication, 63(2), 287-311.

Schuck, A. R. T., \& de Vreese, C. H. (2006). Between risk and opportunity. News framing and its effects on public support for EU enlargement. European Journal of Communication, 21(1), 5-32.

Young, D. (2004). Late-night comedy in election 2000. Its influence on candidate trait ratings and the moderating effects of political knowledge and partisanship. Journal of Broadcasting \& Electronic Media, 48(1), $1-$ 22.

Zaller, J. R. (1992). The nature and origins of mass opinion. New York: Cambridge University Press.

\section{About the Authors}

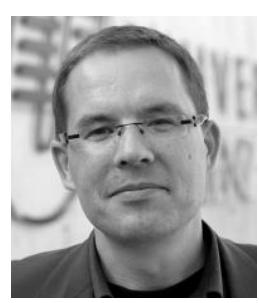

\section{Dr. Jürgen Maier}

Jürgen Maier is Professor of Political Communication at the University of Koblenz-Landau, Germany. His current research focuses on the content and effects of campaign communication with a particular interest on televised debates; media, public opinion, and electoral behavior; processing of political information; experiments in Political Science, and real-time response measurement.

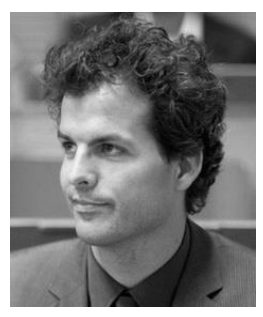

\section{Dr. Berthold Rittberger}

Berthold Rittberger is Professor of International Relations at the University of Munich and co-editorin-chief of the Journal of European Public Policy. His research focuses on European integration and processes of institutional change as well as political representation in the EU.

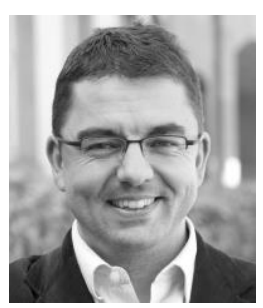

\section{Dr. Thorsten Faas}

Thorsten Faas holds an MSc in European Politics and Policy from the London School of Economics and Political Science. He received his PhD in 2008 from the University of Duisburg-Essen. Since 2012, he is a Professor of Political Science at the Johannes Gutenberg-Universität Mainz. In his research, he focuses on elections, electoral behavior and political communication. 
Appendix. Question wording and coding.

EU most appropriate level to solve most pressing problem: "What do you think would be the most appropriate level to deal with those three problems that you have just mentioned?"; "European level" (1), "National level" (0), "Regional/local level" (0).

Development of the economic situation of the EU: "Thinking about the economy in the European Union as a whole, would you say that over the past year the economy in the EU..."; "has improved by much" (2), "has improved somewhat" (1), "stayed about the same" (0), "got somewhat worse" (-1), "got much worse" (-2).

Expected development of the economic situation of the EU: "What about the next 12 months? Do you expect the economy, in the European Union as a whole,..."; "to get much better" (2), "to get somewhat better" (1), "to stay about the same" (0), "to get somewhat worse" (-1), "to get much worse" (-2).

Comparison of the economic situation in Germany and the EU: "If you compare the state of the economy in your country with the European Union as a whole, would you say the state of the economy in your country is..."; "much better than in the EU" (2), "somewhat better than in the EU" (1), "about the same as in the EU" (0), "somewhat worse than in the EU" (-1), "much worse than in the EU" (-2).

Responsibility of the EU for economic situation in Germany: "What do you think-to what extent is each of the following institutions responsible for the economic conditions in your country?" The EU; 11-point scale from -5 ("not at all responsible") to +5 ("fully responsible").

Financial support for economically depressed member states "Do you agree or disagree that in times of crisis countries that are better off should give financial help to another EU member state facing severe economic and financial difficulties?"; "totally agree" (3), "agree" (2), "disagree" (1), "totally disagree" (0).

EU good thing: "Generally speaking, do you think that your country's membership of the European Union is a good thing, a bad thing, or neither good nor bad?"; "good thing" (1), "neither good nor bad" (0), "bad thing" (-1).

Further integration: "Some say European integration (i.e. the economic and political cooperation between the member states) should be pushed further. Others say it has already gone too far. And what is your opinion on this issue?" 11-point scale from +5 ("European integration should be pushed further") to -5 ("European integration has already gone too far").

Trust in EU: "How much of the time do you think you can trust the following groups and institutions to do what is right? The European Union"; "almost always" (2), "frequently" (1), "about half of the time" (0), "once in a while" (-1), "almost never" (-2).

Trust in EU Commission: "How much of the time do you think you can trust the following groups and institutions to do what is right? The European Commission"; "almost always" (2), "frequently" (1), "about half of the time" (0), "once in a while" (-1), "almost never" (-2).

Fear: "If you think about the European Union: To what extent does the EU trigger fear in you? Fear", 7-point scale from -3 ("not at all") to +3 ("to a great extend").

Anger: "If you think about the European Union: To what extent does the EU trigger anger in you? Anger", 7-point scale from -3 ("not at all") to +3 ("to a great extend").

Hope: "If you think about the European Union: To what extent does the EU trigger hope in you? Hope", 7-point scale from -3 ("not at all") to +3 ("to a great extend").

Joy: "If you think about the European Union: To what extent does the EU trigger joy in you? Joy", 7-point scale from -3 ("not at all") to +3 ("to a great extend").

Disgust: "If you think about the European Union: To what extent does the EU trigger disgust in you? Disgust", 7-point scale from -3 ("not at all") to +3 ("to a great extend").

Contempt: "If you think about the European Union: To what extent does the EU trigger contempt in you? Contempt", 7point scale from -3 ("not at all") to +3 ("to a great extend").

Political knowledge: "For each of the following statements about the EU, please mark whether you think they are true or false: "The EU currently consists of 28 member states" (true), "The members of the European Parliament are directly elected by the citizens of each member state" (true), "Norway is a member of the EU" (false). Based on the answers to these statements a 4-point scale ranging from 0 ("none of the statements were an- 
swered correctly") to 3 ("all statements were answered correctly") was calculated. For some analyses the scale was dichotomized into "low political knowledge/political novices" (i.e., none or one statement correctly answered) (0) vs. "high political knowledge/political experts" (i.e., two or three statements correctly answered) (1).

Ideology: "In political matters people talk of "the left" and "the right". What is your position?" 11-point scale from 0 ("left") to 10 ("right").

Gender: male (0), female (1). 